\title{
Semi-automated landform classification for hazard mapping of soil liquefaction by earthquake
}

\author{
Takayuki Nakano $^{\mathrm{a}}$ \\ ${ }^{a}$ Geospatial Information Authority of Japan, Tsukuba, Ibaraki, Japan; nakano-t96fj@mlit.go.jp
}

\begin{abstract}
Soil liquefaction damages were caused by huge earthquake in Japan, and the similar damages are concerned in near future huge earthquake. On the other hand, a preparation of soil liquefaction risk map (soil liquefaction hazard map) is impeded by the difficulty of evaluation of soil liquefaction risk. Generally, relative soil liquefaction risk should be able to be evaluated from landform classification data by using experimental rule based on the relationship between extent of soil liquefaction damage and landform classification items associated with past earthquake. Therefore, I rearranged the relationship between landform classification items and soil liquefaction risk intelligibly in order to enable the evaluation of soil liquefaction risk based on landform classification data appropriately and efficiently. And I developed a new method of generating landform classification data of 50-m grid size from existing landform classification data of 250-m grid size by using digital elevation model (DEM) data and multi-band satellite image data in order to evaluate soil liquefaction risk in detail spatially. It is expected that the products of this study contribute to efficient producing of soil liquefaction hazard map by local government.
\end{abstract}

Keywords: Landform classification data, hazard map, soil liquefaction risk, digital elevation model (DEM)

\section{Preface}

A lot of liquefaction damages occurred in the Great East Japan Earthquake in 2011 and the Kumamoto earthquake in 2016, and similar damages are concerned in near future huge earthquake in Japan. Therefore, it is important to evaluate liquefaction risk in advance in order to reduce liquefaction damage. However, a preparation rate of the soil liquefaction risk map (soil liquefaction hazard map) is low ca. 20\% throughout Japan (as of September 2016). As soil liquefaction hazard maps are created by local governments, various factors such as the financial and technical problems are considered for the low preparation rate. As a technical problem, difficulty of liquefaction risk evaluation method for staffs of local government is considered.

There are engineering method using physical models and geographical method using experimental rules for soil liquefaction risk evaluation. In the former method, there are the "FL method" (e.g. Architectural Institute of Japan, 2001) and "PL method" (e.g. Iwasaki et al., 1980; Japan Road Association, 2002) etc. "FL method" evaluates by obtaining the resistivity to liquefaction (FL value) for each liquefaction target layer from the physical characteristics of ground and the input ground motion. "PL method" evaluates by obtaining the liquefaction potential index (PL value) which comprehensively evaluated FL value up to a depth of $20 \mathrm{~m}$. In the later method, soil liquefaction risk is estimated from the evaluation standard of soil liquefaction risk on each landform based on experimental rule derived from relationship between landform classification items and past liquefaction damage cases.

The engineering method makes it possible to evaluate more accurately when accurate ground physical properties are obtained. However, it is difficult to homogeneously obtain the physical properties of a wide range of ground, so it is difficult to evaluate extended area, and specialized knowledge is also required. In contrast, the geographical method is possible to evaluate extended area relatively easily if there is landform classification data. It is known by the soil liquefaction study so far that soil liquefaction occurs in ground which is loose sand layer and shallow groundwater levels (e.g. Tohno, 1992). As places (landform) where such conditions are satisfied, reclaimed land of former river channel and former water area, lowland between sand dunes and sandbar, etc. are applicable. Soil liquefaction occurred concentrating on these landforms even in the past earthquakes (e.g. Kotoda and Wakamatsu, 1984; Wakamatsu et al., 2006; Sen-na et al., 2012; Aoyama et al., 2014). Therefore, if there is landform classification data indicating the terrain type on the spot, it is possible to evaluate the relative risk of liquefaction from experimental rules based on past cases of liquefaction damage, and several evaluation methods are suggested (e.g. Earthquake Disaster Countermeasures Division, Disaster Prevention Bureau, National Land Agency, 1999; Wakamatsu et al., 2005; Matsuoka et al., 2011). As landform classification data maintained on the whole country in Japan, there are landform classification data of 250-m grid size (Wakamatsu and Matsuoka, 2009). However, since this method is qualitative in evaluation and there are many evaluation methods, there is a problem that options for soil liquefaction hazard map creation staffs are complicated. In addition, the spatial resolution of landform classification data for evaluating soil liquefaction risk is often not sufficient. Actually, in the case of the Great East Japan Earthquake in 2011, the soil liquefaction hazard map could not fully extract the 
actual damaged area because of the coarse spatial resolution of the landform classification data although the soil liquefaction hazard map has been prepared. For this reason, it is required to develop landform classification items and liquefaction risk evaluation method which are easier to understand even staffs of local governments, and to create landform classification data with higher spatial resolution than before covering the plains of the whole country in Japan.

Therefore, in this study, I rearranged the relationship between landform classification items and soil liquefaction risk intelligibly in order to enable the evaluation of soil liquefaction risk based on landform classification data appropriately and efficiently. And I developed a new method of generating landform classification data of $50-\mathrm{m}$ grid size from existing landform classification data of 250-m grid size by using digital elevation model (DEM) data and multiband satellite image data in order to evaluate soil liquefaction risk in detail spatially.

\section{Outline of this study}

2.1 Creation the systematic chart between landform classification items and evaluation standard of soil liquefaction risk for producing soil liquefaction hazard map

At first, I created a systematic chart integrated landform classification items on the plains and evaluation standard of soil liquefaction risk for producing soil liquefaction hazard map (Nakano et al., 2015). The systematic chart was created by taking a lot of existing study cases of relationship between landform classification data and soil liquefaction risk (e.g. Earthquake Disaster Countermeasures Division, Disaster Prevention Bureau, National Land Agency, 1999; Wakamatsu et al., 2005; Midorikawa and Matsuoka, 1995; Koarai, 2010; Matsuoka et al., 2011; Geotechnical Engineering Society Hokuriku Branch, Hokuriku Regional Development Bureau, Ministry of Land, Infrastructure and Transport, 2012) and quantitative analysis result by using actual cases of the Great East Japan Earthquake in 2011 around Kanto district in Japan into consideration. In the quantitative analysis based on the actual cases in the Kanto district, liquefaction occurrence rate for each landform classification items was calculated by superimposing liquefaction damage distribution information associated with the Great East Japan Earthquake in 2011 (Kanto Regional Development Bureau, Ministry of Land, Infrastructure and Transport and The Japanese Geotechnical Society, 2011) and detailed landform classification data produced by Geospatial Information Authority of Japan, and it was used to judge the liquefaction risk magnitude. In this process, I simplified by means of reduction of the number of landform classification items and intensiveness of landform classification items belonging to same risk level by specializing soil liquefaction hazard map.
2.2 Development the new method of generating landform classification data of 50-m grid size

Secondly, I derived a classification rules of binary trees in order to generate landform classification data of 50-m grid size based on the systematic chart from existing landform classification data of $250-\mathrm{m}$ grid size in combination with geomorphological indices (gradient, relief energy etc.) calculated from DEM data and normalized indices (NDVI etc.) calculated from multiband satellite imagery data. For development, five districts (Kanto 1 site, Kanto 2 site, Fukuoka site, Oita site, Miyazaki site) were selected as the model district. The data used for development are 250-m grid landform classification data, 5-m and 10-m grid DEM data of Fundamental Geospatial Data, and multiband satellite image data (TERRA / ASTER: 15-m and 30-m resolution).

Here, I aimed to establish a process to generate landform classification data of $50-\mathrm{m}$ grid size by assigning classification rules to land form classification data of 250-m grid size, with reference to the method of Ishii et al. (2007) and Ishii et al. (2011).

\section{Systematic chart integrated landform classification items and evaluation standard of soil liquefaction risk for producing soil liquefaction hazard map}

Table 1 shows the systematic chart integrated landform classification items and evaluation standard of soil liquefaction risk for producing soil liquefaction hazard map. In the Table 1, the corresponding landform classification items are displayed for each potential level of soil liquefaction. I also created a systematic table that shows the potential level of soil liquefaction for each landform classification items and also corresponds to the past landform classification items.

In addition, the "natural levee" is divided at the boundary of 5-m in relative height, and the "valley plain / coastal plain" and "alluvial fan" are each divided at the gradient of $1 / 100$. These are calculated using DEM data.

\begin{tabular}{|c|c|}
\hline $\begin{array}{l}\text { Potential } \\
\text { level of soil } \\
\text { liquefaction }\end{array}$ & Landform classification items \\
\hline Very big & $\begin{array}{l}\text { - Former river channel } \\
\text { - Filled land } \\
\text { - Edge of Sand dune adjacent } \\
\text { to lowland } \\
\text { - Lowland between sand dunes } \\
\text { and sandbar }\end{array}$ \\
\hline Big & $\begin{array}{l}\text { - Natural levee (relative height } \\
\text { less than 5-m) } \\
\text { - Valley plain / Costal plain } \\
\text { (gradient less than } 1 / 100 \text { ) }\end{array}$ \\
\hline
\end{tabular}




\begin{tabular}{|c|c|}
\hline & $\begin{array}{l}\cdot \text { Back marsh } \\
\text { - Dry riverbed } \\
\text { - Reclaimed land }\end{array}$ \\
\hline Slightly big & $\begin{array}{l}\text { - Alluvial fan (gradient less } \\
\text { than } 1 / 100 \text { ) } \\
\text { - Natural levee (relative height } \\
5 \text {-m or more) } \\
\text { - Marine sand and gravel bars } \\
\text { - Valley plain / Costar plain } \\
\text { (gradient } 1 / 100 \text { or more) }\end{array}$ \\
\hline Small & $\begin{array}{l}\text { - Holocene terrace } \\
\text { - Alluvial fan (gradient 1/100 } \\
\text { or more) } \\
\text { - Sand dune }\end{array}$ \\
\hline $\begin{array}{l}\text { Almost } \\
\text { nothing }\end{array}$ & - Pleistocene terrace \\
\hline
\end{tabular}

Table 1. Systematic chart integrated landform classification items and evaluation standard of soil liquefaction risk for producing soil liquefaction hazard map

\section{New method of generating landform classification data of 50-m grid size}

\subsection{Derivation of classification rules}

Derivation of classification rules was carried out in the following procedure.

1)Split 250-m grid size landform classification data into 50-m grid size

2)Re-classification of detailed landform classification data items into landform classification items for producing soil liquefaction hazard map

3)Correspondence between the above data 1 and data 2 by overlay analysis

4)Calculation of eight geomorphological indices (average elevation, average gradient, relief energy, ground opening, etc.) and satellite image data normalization indices (NDVI, NDSI, etc.) in each 50$\mathrm{m}$ grid

5)Characteristic extraction of each indicator of above 4 . for each combination of landform classification items in above 3., and derivation of provisional classification rule

6)Demonstration and verification of data based on provisional classification rules of above 5., and derivation of classification rules by modification of provisional classification rules based on verification results

The classification rules derived in above 6 . are as follows. For example, when the place which is "Hill" in the $250 \mathrm{~m}$ grid landform classification data is "Pleistocene terrace" in the case of 50-m grid size data, the geomorphological characteristics (geomorphological indices) and land covering characteristics (normalization indices) were examined, and a conversion rule was created based on the characteristic amount as a threshold value. Table 2 shows the example of classification rules in the case of "Hill" in the 250-m grid landform classification data. Here, the processing is done in order from the top.

\begin{tabular}{|c|c|c|c|c|c|}
\hline $\begin{array}{l}\text { 250-m grid } \\
\text { landform } \\
\text { classificati } \\
\text { on items }\end{array}$ & $\begin{array}{l}\text { Landform } \\
\text { classificati } \\
\text { on items } \\
\text { after } \\
\text { conversion }\end{array}$ & $\begin{array}{l}\text { Rule } \\
1\end{array}$ & Rule 2 & $\begin{array}{l}\text { Rule } \\
3\end{array}$ & Rule 4 \\
\hline Hill & $\begin{array}{l}\text { Pleistocen } \\
\text { e terrace }\end{array}$ & $\begin{array}{l}\text { Wettabili } \\
\text { ty }<1\end{array}$ & $\begin{array}{l}\text { Undergrou } \\
\text { nd opening } \\
<87\end{array}$ & $\begin{array}{l}\text { Gradient } \\
<5\end{array}$ & \\
\hline Hill & $\begin{array}{l}\text { Valley } \\
\text { plain/ } \\
\text { Flood } \\
\text { plain }\end{array}$ & $\begin{array}{l}\text { Surface } \\
\text { texture } \\
>=5\end{array}$ & $\begin{array}{l}\text { Gradient } \\
<5\end{array}$ & $\begin{array}{l}\text { Wettabili } \\
\text { ty }>=2\end{array}$ & \\
\hline Hill & $\begin{array}{l}\text { Piedmont } \\
\text { aggraded } \\
\text { slope }\end{array}$ & $\begin{array}{l}\text { Relief } \\
\text { energy } \\
<12\end{array}$ & $\begin{array}{l}\text { Undergrou } \\
\text { nd opening } \\
>=85\end{array}$ & $\begin{array}{l}\text { Wettabili } \\
\text { ty }>=0.5\end{array}$ & Gradient $<8$ \\
\hline Hill & $\begin{array}{l}\text { Former } \\
\text { river } \\
\text { channel }\end{array}$ & $\begin{array}{l}\text { Gradient } \\
<5\end{array}$ & $\mid \begin{array}{l}\text { Surface } \\
\text { texture }<5\end{array}$ & $\begin{array}{l}\text { Ground } \\
\text { opening } \\
>=85\end{array}$ & $\begin{array}{l}\text { Wettability } \\
p=3\end{array}$ \\
\hline Hill & Filled land & $\begin{array}{l}\text { NDWI } \\
<0.2\end{array}$ & $\begin{array}{l}\text { NDSI }<(- \\
0.1)\end{array}$ & $\begin{array}{l}\text { Ground } \\
\text { opening } \\
>=87\end{array}$ & \\
\hline Hill & $\begin{array}{l}\text { Mountain } \\
\text { slope }\end{array}$ & & & & \\
\hline
\end{tabular}

Table 2. Classification rules in the case of "Hill" in the 250-m grid landform classification data

\subsection{Development an automated landform classification data generation program}

Based on the classification rules derived above, we developed a program to automatically generate $50-\mathrm{m}$ grid size landform classification data using existing 250-m grid size landform classification data with DEM and multi-band satellite image data. This program runs on a commercially available GIS. The processing flow of the program is shown in Fig.1. Automatically generated 50$\mathrm{m}$ grid size landform classification data contains some noise, so I tried to improve by applying filtering and other information of former river channel and former water area information. The landform classification data of 50-m grid size generated from the classification rules semi-automatically with filtering was almost classified properly although the data has noise data partially (Fig.2). 


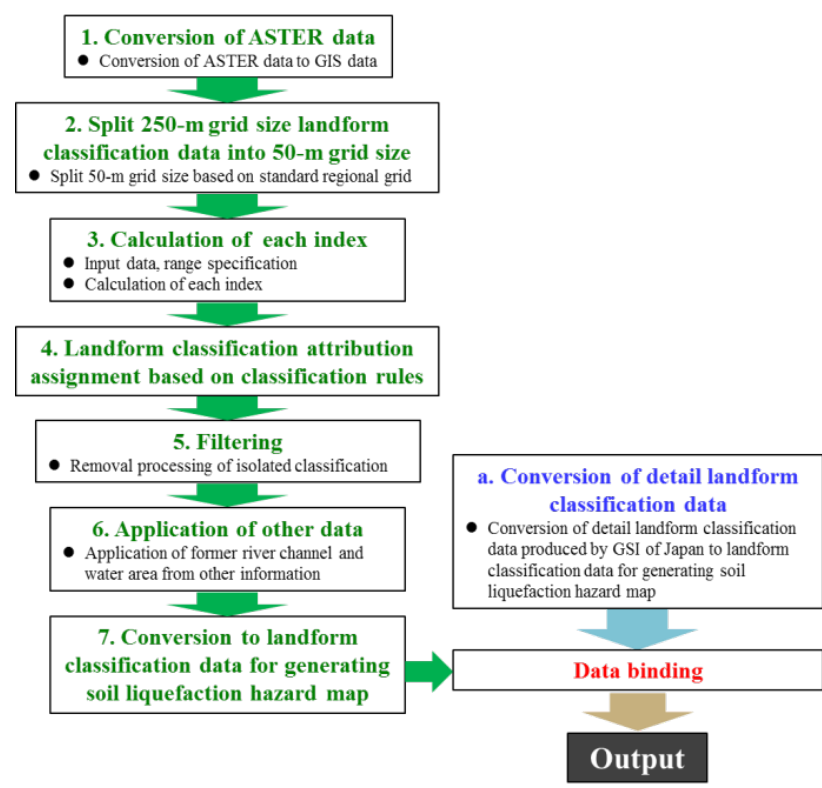

Fig. 1. Processing flow of the automated landform classification data generation program
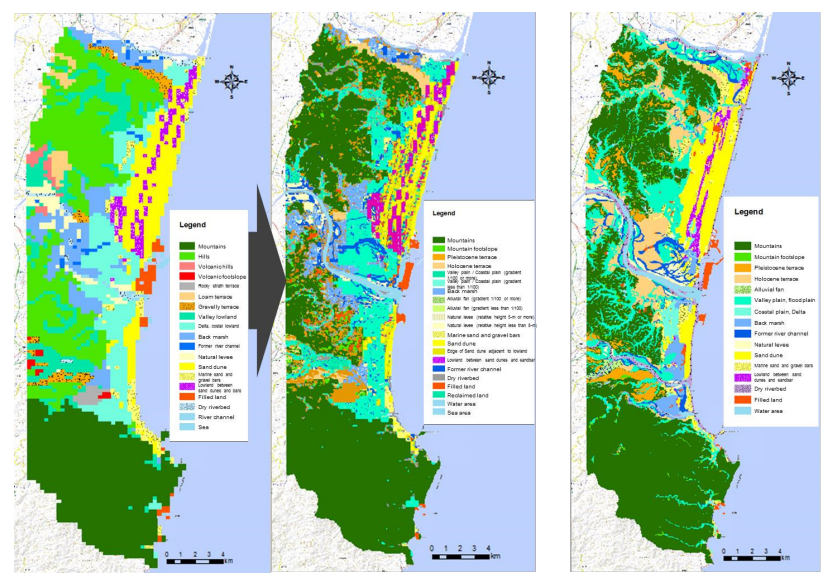

Fig. 2. 50-m grid landform classification data (middle) automatically generated from the $250-\mathrm{m}$ grid landform classification data (left), and 50-m grid landform classification data based on detailed landform classification data produced by GSI of Japan (right)

\subsection{Suggestion of semi-automated creation method of landform classification data of 50-m grid size}

The processing result by the above-mentioned automated generation program is almost appropriately generated, but it includes some misclassification. Landform classification items with similar geomorphological index and normalized index (for example, "Valley plain / Coastal plain" and "Back marsh") are likely to misclassify. Especially, as the current DEM data is used, it is difficult to automatically generate buried landforms such as former river channel and former water area that do not appear in the current landform. Also, artificial landform such as road embankment becomes a misclassification source.

Therefore, I decided to reliably reclassify former river channel and artificial landform by using a traditional aerial photo interpretation method, and I proposed a method to be a semi-automated creation method of landform classification data of 50-m grid size as a whole (Fig.3).

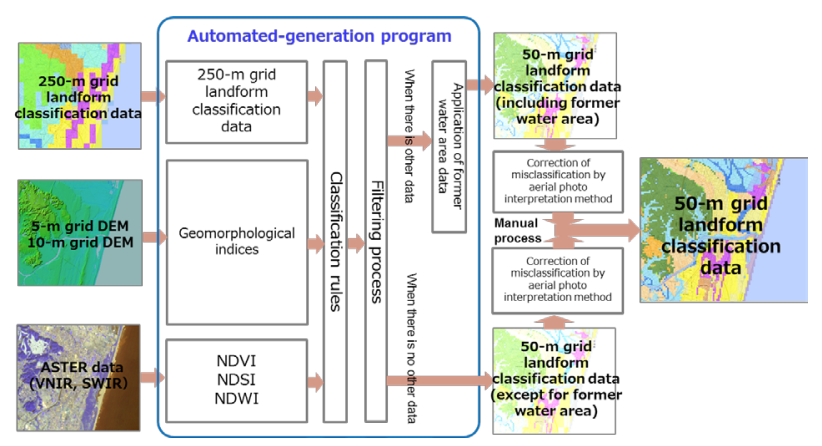

Fig. 3. Semi-automated creation flow of $50-\mathrm{m}$ grid landform classification data

\section{Effects of this study results}

\subsection{Improvement of intelligibility of the evaluation standard of soil liquefaction risk}

In this study, I aimed to prepare landform classification items and liquefaction risk assessment methods which are easier to understand even for staffs of local governments. Therefore, I conducted questionnaires for general staffs of local governments on which evaluation standards are most easily understood among the evaluation standard created in this study and the usual two standards. As a result, about two-thirds of the 125 respondents replied that the risk evaluation standard of this study is most easily understood.

\subsection{Improvement of efficiency of landform classification data creation work}

I estimated the extent to which the efficiency of the semiautomated creation method proposed above is more efficient than the usual method. As a result, it was expected that the number of working days in the aerial photo interpretation process part would be about one fifth as compared with the case of creating the landform classification data only by the traditional aerial photo interpretation method. Since it is expected that the work volume will be about two-fifths even in all processes, it was shown that work can be made sufficiently efficient.

\subsection{Improvement of accuracy of soil liquefaction risk evaluation}

The liquefaction risk evaluation standard and the 50-m grid landform classification data by automated generation program created in this study are verified to what effective against the actual liquefaction damage. The liquefaction risk evaluation standard in Table 1 were applied to the 50-m grid landform classification data by automated generation program in this study in the Kanto area where liquefaction occurred frequently associated with the Great East Japan Earthquake in 2011. Then, it is compared with actual liquefaction damage area (Fig. 4). 
As a result, the landform classification data of 50-m grid size was able to identify actual soil liquefaction zone as very high risk zone of soil liquefaction more exactly than other landform classification data. In other words, it was shown that the landform classification data effective for liquefaction risk evaluation can be generated automatically in a place where artificial modification is not so large and buried landform such as former river channel can be complemented by other information.

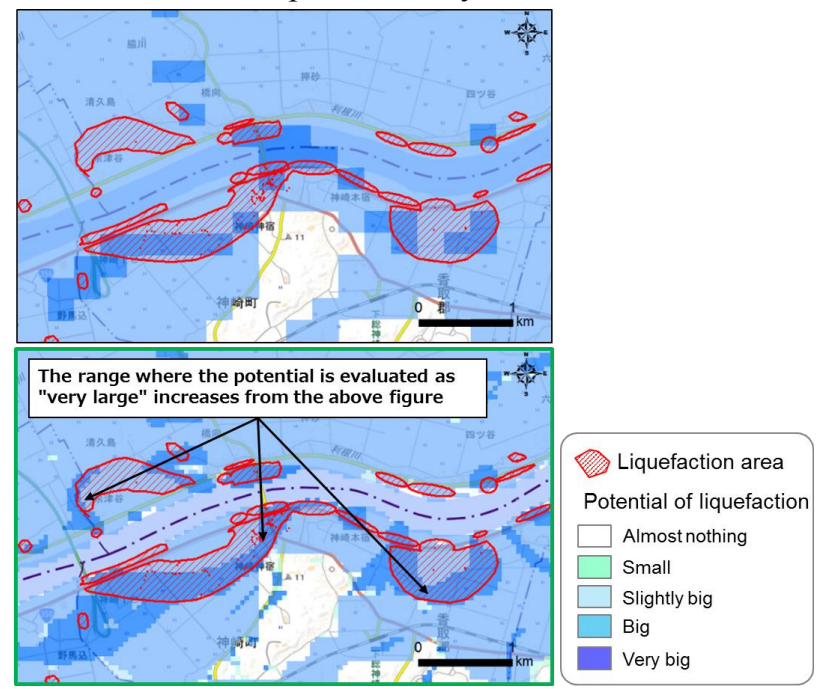

Fig. 4. Comparison between actual liquefaction areas and liquefaction risk evaluation result. Upper figure: Case using 250-m grid landform classification data, lower figure: Case using $50-\mathrm{m}$ grid landform classification data of automated generation by this study.

\section{Summary and Challenges}

In this study, I rearranged the relationship between landform classification items and soil liquefaction risk intelligibly in order to enable the evaluation of soil liquefaction risk based on landform classification data properly and effectively. And I developed a new method of generating landform classification data of $50-\mathrm{m}$ grid size from existing landform classification data of $250-\mathrm{m}$ grid size by using digital elevation model (DEM) data and remote sensing data in order to evaluate soil liquefaction risk in detail spatially.

As a result, the systematic chart for liquefaction risk evaluation is considered to be effective when local governments conduct liquefaction risk evaluation using landform classification data. Also, it is expected to be used to create liquefaction hazard map and as disaster prevention and geography education material. However, generation of landform classification data by the automated creation program is insufficiently verified outside the model area, and since it is affected by artificially modified landforms, it is necessary that the traditional aerial photo interpretation method is used together at the present time. Therefore, when using this result in practical use, it is necessary to construct concrete work procedures including combination of traditional aerial photo interpretation method and information of different source.

\section{Acknowledgements}

In the questionnaire survey of liquefaction risk evaluation standard chart, cooperation was obtained from several local governments and local outsourcing organizations of the country and prefecture. I appreciate their support.

\section{References}

Aoyama, M., Koyama, T. and Une, H. (2014). Geomorphological Condition and Land History of Liquefaction Damaged Sites in the Lower Part of the Tone River Lowland Induced by the 2011 off the Pacific Coast of Tohoku Earthquake. Geograhical Review of Japan Series A, 87(2), 128-142. (in Japanese with English abstract)

Architectural Institute of Japan (2001). Architectural foundation design guidelines. (in Japanese)

Earthquake Disaster Countermeasures Division, Disaster Prevention Bureau, National Land Agency (1999). Zoning manual of liquefaction area. (in Japanese)

Geotechnical Engineering Society Hokuriku Branch, Hokuriku Regional Development Bureau, Ministry of Land, Infrastructure and Transport (2012). Liquefaction potential map in Niigata Prefecture. http://www.hrr.mlit.go.jp/ekijoka/niigata/niigata.html. Accessed 24 Feb 2017. (in Japanese)

Ishii, K., Midorikawa, S. and Miura, H. (2007). Detailed Mapping of Engineering Geomorphologic Classification Using Digital Elevation Model and Satellite Image. Journal of Social Safety Science, 9, 121-129. (in Japanese with English abstract)

Ishii, K., Midorikawa, S. and Miura, H. (2011). Detailed Mapping of Engineering Geomorphologic Classification Using High Resolution Satellite Image and Digital Elevation Model. Journal of Social Safety Science, 14, 57-66. (in Japanese with English abstract)

Iwasaki, T., Tatsuoka, F., Tsuneda, K. and Yasuda, S. (1980). On prediction of degree of ground liquefaction during earthquake. Soil mechanics and foundation engineering, 28(4), 23-29. (in Japanese)

Japan Road Association (2002). Road bridge specification book and commentary $\mathrm{V}$, earthquake resistant design edition. (in Japanese) Kanto Regional Development Bureau, Ministry of Land, Infrastructure and Transport and The Japanese Geotechnical Society (2011). Report of clarify facts of land liquefaction phenomena in Kanto district induced by the 2011 off the Pacific coast of Tohoku Earthquake. 65pp.

Koarai, M. (2010). Utilization of geospatial information for disaster mitigation. Geography, May issue, (pp. 6268). Tokyo: Kokon Shoin. (in Japanese)

Kotoda, K. and Wakamatsu, K. (1984). Geomorphological consideration on site conditions of liquefied sites during Nihonkai-Chubu earthquake. Soil mechanics and foundation engineering, 32(9), 59-63. (in Japanese)

Matsuoka, M., Wakamatsu, K. and Hashimoto, M. (2011). Liquefaction Potential Estimation Based on the 
7.5-arc-second Japan Engineering Geomorphologic Classification Map. Journal of Japan Association for Earthquake Engineering, 11(2), 20-39. (in Japanese with English abstract)

Midorikawa, S. and Matsuoka, M. (1995). GIS-Based Integrated Seismic Hazard Evaluation using the Digital National Land Information. BUTSURI-TANSA, 48(6), 519-529. (in Japanese with English abstract)

Nakano, T., Koarai, M. and Une, H. (2015). Reconsideration of hazard assessment standard for land liquefaction using the landform classification data. Journal of Geography (Chigaku Zasshi), 124(2), 259271. (in Japanese with English abstract)

Sen-na, S., Hasegawa, S., Maeda, N. and Fujiwara, H. (2012). Liquefaction Damage of The Tonegawa Basin Caused by The 2011 off the Pacific coast of Tohoku Earthquake, Journal of Japan Association for Earthquake Engineering, 12(5), 143-162. (in Japanese with English abstract)

Tohno, I. (1992). Achievement of liquefaction / liquefaction disaster investigation research of ground. Journal of Agricultural Civil Society, 60(9), 7-12. (in Japanese)

Wakamatsu, K. and Matsuoka, M. (2009). Development of GIS-based 7.5-arc-second Japan Engineering Geomorphologic Classification Map. Proceedings of the 3rd Symposium "Construction of integrated underground structure database" Interim report of research results, 15-20. (in Japanese with English abstract)

Wakamatsu, K., Matsuoka, M., Sugiura, M., Kubo, J. and Hasegawa, K. (2005). Japan Engineering Geomorphologic Classification Map. University of Tokyo Press.

Wakamatsu, K., Yoshida, N. and Kiku, H. (2006). Liquefaction during the 2004 Niigata-ken Chuetsu Earthquake -General Aspect and Geotechnical and Geomorphologic Conditions-. Journal of Japan Society of Civil Engineers, Ser. C, 62(2), 263-276. (in Japanese with English abstract) 